\title{
AN ANALYSIS OF TRANSLATION OF IDIOMS USED IN CONAN DOYLE'S NOVEL “A STUDY IN SCARLET”
}

\author{
Farida Agoes \\ English Dept, Politeknik Negeri Bandung, Indonesia
}

\begin{abstract}
The article is about an analysis of translation of idioms in the novel by Conan Doyle entitled A Study in Scarlet. Translating idioms is often problematic for a translator because idioms are specific to a single language and rarely have the equivalent in other languages. Therefore, this study was conducted to find out the types of idioms used in the English version of the novel, to find out the strategies used by the translator of the Indonesian version of the novel in translating the English idioms, and to find out the accuracy, acceptability and readability of the translation of the idioms in the novel. In analysing the idioms and their translation, qualitative method was used, and the theories by Fernando (1996), Baker (2011) and Nababan, Nuraini, and Sumardiono (2012) were also used. The finding of the analysis shows that from 60 idioms found, semi-idiom is the type of idioms which is frequently found in the novel (31 idioms or 52\%). Besides, it is revealed that translating the idioms by paraphrasing is the strategy which is mostly used by the translator in translating the idioms (38 idioms or 63\%). In addition, it is revealed that the translation of idioms in the novel is accurate and acceptable although it is less readable. So, the quality of translation of idioms in the novel is good although it can be still improved.
\end{abstract}

Keywords: accuracy, acceptability and readability of translation, idiom, translation, translation strategies

\section{Introduction}

Translation plays an important role in this era. Although languages vary widely across universe, people around the world can still communicate by the help of translation. Newmark (1988) stated, "Translation is rendering the meaning of a text into another language in the way that the author intended the text." It means that a translated text needs to deliver the same message as the original text. However, there is a possibility that a translated text has any meaning distortion which can lead the readers to miss interpret its message. So, it is important for translators to produce good translated texts which are accurate, acceptable and readable.

Translating idioms is not easy for translators since idioms are one of the elements of a language which rarely have the equivalent in other languages. Idioms are also influenced by culture, and every language has their own idioms. As Adelnia and Dastjerdi (2011) said, "Not all idioms have direct equivalents in another language because they are linguistic expressions which are typical for a language and specific to a single culture" (p. 879). Idioms can also be 
hard to be understood since sometimes the meaning cannot be deduced from the words which form them. Baker (2011) said in her book that idioms frequently convey the meanings which cannot be comprehended from their individual component. That is why idioms are needed to be understood as a whole. Those make the idioms hard to be translated.

Literary texts such as novels which are the long printed stories about imaginary characters and events may contain a lot of idioms since idioms help the language used in the novel become more colourful. There are a wide range of novels which were translated in order to provide them accessible to broader readers. One of the novels is A Study in Scarlet written by Conan Doyle. This novel is the first novel introducing the famous character, Sherlock Holmes. The novel was chosen to be analysed because it has been translated into several languages including Indonesian. Up to now, the Indonesian version of the novel is still published and can be found easily although this novel was first published in 1887. Furthermore, this novel may contain a lot of English idioms which need to be translated in the Indonesian version of the novel.

Those are the background for conducting this research. It is essential for the translators to be familiar with idioms so that they can recognize them in the text to translate. The translators also need to know the strategies for translating the idioms so that they can choose the proper strategies for translating the idioms. Those can help them to produce the accurate, acceptable and readable translation of idioms.

To uncover and understand more about the translation of idioms, an analysis was conducted into a novel entitled A Study in Scarlet. The aims of this study are to find out the types of idioms appeared in the English version of A Study in Scarlet and to find out the strategies used by the translator of the Indonesian version of A Study in Scarlet in translating the idioms. In addition, another aim is to find out the accuracy, acceptability and readability of the translation of idioms in A Study in Scarlet.

\section{Literature Review}

Translating idioms is not an easy job. Still some experts have provided us with some strategies of translation, problems cannot be avoided. There are some articles discussing these problems. Ligita (2009) in her research found that in translating of idioms in the dialogue of cartoons she studied, the element of meaning got preference as 25 of 34 unmotivated idioms reduced to meaning without transferring the idiomatic form. She said that one of the reasons for that was the very nature of subtitling, i.e. a limited number of characters and a fast rate of speech. In her conclusion she said that subtitling of motivated idioms is less challenging. Based on her research, Margarita (2010) said that even though there were a number of exact equivalents in the target language, a lack of equivalent idioms in Russian language was still found and the most prevailing translation strategy turned out to be translation by description according to Vigogradov. Amir (2012) found that there were a number of factors which should be considered in order to translate idiomatic expression correctly. According to him, those important factors include socio-linguistic elements, cultural aspect, linguistic and stylistic consideration and meta-lingual factors. Monireh (2013) said that there were no 
ready-made, fixed strategies to be prescribed to translator dealing with idioms and it was up to the translator to draw the best strategies while translating idioms. That is why a translator needs to be familiar with SL idioms and learn ways to recognize the ones they do not know.

Those articles above discussed only the difficulty of translating idioms and the strategy used. Articles discussing analysis of the quality of idiom translation in terms of the accuracy, acceptability and readability are rarely discussed. So the gap was found.

Actually, the quality of the translated text is important to be considered since it can show whether the translation result is appropriate or not. Therefore, based on the gap found, beside analysing the types of idioms and the translation strategies used by the translator in translating the idioms, this study analyzes the quality of the idiom translation in the novel in terms of the accuracy, acceptability and readability.

Here are several theories related to the study which were used in conducting the study. The theories are about idioms, idiom classification, translation, translation strategies, and about accuracy, acceptability and readability of translation.

Oxford Advanced Learner's Dictionary defined an idiom as "a group of words whose meaning is not clear from the meaning of its individual words and which must be learnt as a whole unit" (2010, p. 744). The COBUILD Dictionary of Idioms added, "Idioms are typically metaphorical: they are effectively metaphors which have become 'fixed' or 'fossilized'." A metaphor isan expression which describes someone or something by referring to something else. In short, idiom is a combination of words which is needed to be understood as a whole, and it cannot be comprehended literally. In some cases, it can be metaphorical. Oxford Advanced Learner's Dictionary gave an example. The words 'let the cat out of the bag' is an idiom which means telling a secret by mistake. This shows that the meaning of an idiom is so different with the literal meaning of it although sometimes the meaning of an idiom can be easily comprehended.

Many experts have classified idioms based on different basis. However, the classification which was used in this study is the one proposed by Fernando (1996). This classification was used because it classifies the idioms based on 'the spectrum of idiomaticity' or the transparency of the meaning of idioms. It is based on the semantic or the study of meaning. The following is Fernando's classification of idioms (As cited in Leah, 2012): 
Table 1 Fernando's Classification of Idioms (1996)

\begin{tabular}{|l|l|l|}
\hline \multicolumn{1}{|c|}{ Types } & \multicolumn{1}{|c|}{ Description } & \multicolumn{1}{c|}{ Example } \\
\hline Pure idioms & $\begin{array}{l}\text { The meaning of pure idioms } \\
\text { cannot be understood by looking } \\
\text { at the meanings of the words that } \\
\text { make up the idiom. It is always } \\
\text { non literal or not transparent. }\end{array}$ & $\begin{array}{l}\text { There is a surprise } \\
\text { party for Heidi on } \\
\text { Wednesday. Please } \\
\text { don't spill the beans. } \\
\text { (Meaning: to reveal a } \\
\text { secret) }\end{array}$ \\
\hline Semi-idioms & $\begin{array}{l}\text { Semi-idioms are said to have one } \\
\text { or more literal element and one } \\
\text { with non literal element. The } \\
\text { meaning of this type of idioms is } \\
\text { considered semi-transparent. }\end{array}$ & $\begin{array}{l}\text { He tried to break the } \\
\text { cold }\end{array}$ \\
\hline Literal idioms a little \\
tension)
\end{tabular}

Catford (1965, p.20) stated that translation is "the replacement of textual material in one language by equivalent textual material in another language." Newmark (1988) also said, "Translation is rendering the meaning of a text into another language in the way that the author intended the text." To conclude, translation is the activity where a message of a source language (SL) is transferred into a target language (TL) by its equivalent text so that the message can be delivered without misinterpretation.

Translation strategies are problem solving tools which can be used by the translators when they are facing a problem. In this case, the translators use them when they are translating idioms. The idiom translation strategies which are used in this study are the strategies proposed by Baker (2011). Here are four translation strategies proposed by Baker:

Table 2Translation Strategies by Baker (2011)

\begin{tabular}{|l|l|}
\hline \multicolumn{1}{|c|}{ Strategy } & \multicolumn{1}{c|}{ Description } \\
\hline $\begin{array}{l}\text { Using idiom of } \\
\text { similar meaning and } \\
\text { form }\end{array}$ & $\begin{array}{l}\text { It means that the translator needs to find an idiom in the target language } \\
\text { which is equivalent to the source language both in terms of meaning as } \\
\text { well as the form. }\end{array}$ \\
\hline $\begin{array}{l}\text { Using Idiom of } \\
\text { similar meaning but } \\
\text { dissimilar form }\end{array}$ & $\begin{array}{l}\text { The meaning of the target idiom is the same as the original idiom, but } \\
\text { the form is different. }\end{array}$ \\
\hline Paraphrase & $\begin{array}{l}\text { It means that translating a source idiom by giving its meaning in the } \\
\text { target language, it can be a single word or a group of words. }\end{array}$ \\
\hline Omission & $\begin{array}{l}\text { It is used to completely omit the source idiom. The translator usually } \\
\text { chooses this strategy when the idiom which they found is very difficult } \\
\text { to be understood. Actually, omitting the idiom is not wise to be done } \\
\text { since the impact of the idiom will be lost. }\end{array}$ \\
\hline
\end{tabular}


Nababan, Nuraeni, and Sumardiono (2012) proposed a parameter for assessing the quality of translation. They stated that there are three aspects of a good translation which are accuracy, acceptability and readability.

Nababan, Nuraeni and Sumardiono (2012) mentioned that accuracy refers to whether the source text (ST) and the target text (TT) are equivalent or not.They also stated that acceptability refers to whether a translation has been expressed in accordance with the rules, norms and culture of the target language or not. In addition, they defined that readability refers to whether the translation can be understood by the reader or not.

\section{Methodology}

The research methods which are applied in this study is qualitative method. The purpose of qualitative method is "to understand and interpret social actions" (Johnson and Christensen, 2008, as cited in Cawthon, 2013). It involves analysing the data such as "words, pictures, or objects" (Miles and Huberman, 1994, as cited in Neill, 2007). Since the data of this analysis is in the form of words, and understanding the words is essential for doing this kind of study, this method is appropriate to be used. This method is used in identifying the types of idioms and the translation strategies used by the translator of the Indonesian version of the novel in translating the idioms. Besides, it is used in analysing the accuracy, acceptability and readability of the idiom translation of the novel.

The data of this study are the idioms found in the English version of A Study in Scarlet and the translation of those idioms in the Indonesian version of the novel. The novel was written by Conan Doyle. The English version of A Study in scarlet consists of 111 pages whereas the Indonesian version of the novel consists of 208 pages. The English version was printed in 2013 by Merchant Books, and the Indonesian version was printed in 2014 by Shira Media. The novel is divided into two parts, and each part consists of seven chapters. The novel tells about the adventure of Dr John Watson and Sherlock Holmes in solving a strange murder case of Enoch Drebber and his secretary, Joseph Stangerson.

In collecting the data, library study, analysing the document, and distributing the questionnaires were conducted. Library study was done to find several sources related to the study. Document analysis was carried out to find the idioms in the English version of $A$ Study in Scarlet and the translation of those idioms in the Indonesian version of the novel. Besides, distributing the questionnaires to the raters was conducted for scoring the accuracy, acceptability and readability of the translation of idioms.

There were several steps to analyse the data. The first step was identifying the types of idioms based on the clasification by Fernando (1996). Then, the strategies for translating the idioms were identified. The strategies which were used in the analysis are those proposed by Baker (2011). The next step was analysing the accuracy, acceptability and readability of the translation of idioms based on the questionnaire results. The questionnaires were given to the competent raters who have the capability to assess the three aspects. There are three questionnaires for each aspect. In this study, the raters who helped to score the accuracy are the lectures who also have experiences in translation. They are the lecturers of English 
Department of Politeknik Negeri Bandung. The raters who helped to score the acceptability are the lecturer of English Department of Politeknik Negeri Bandung, the lecturer of Indonesian Language of Politeknik Negeri Bandung, and the lecturer of English Department of Widyatama University. For the readability, the raters are two university students and one employee. They enjoy reading novels. After all the steps was done, the last thing to be done was making the conclusion of the findings.

\section{Result and discussion}

The study has been conducted in the purpose of 1) to find out the types of idioms used in the English version of A Study in Scarlet, 2) to find out the strategies used by the translator of the Indonesian version of A Study in Scarlet in translating the idioms, and 3) to find out the accuracy, acceptability and readability of the translation of idioms in A Study in Scarlet.

\section{Idiom Types}

In A Study in Scarlet novel written by Conan Doyle, 60 idioms were found. The idioms have been categorised based on the typology by Fernando (1996).

Table 3 Classification of idioms in A Study in Scarlet

\begin{tabular}{|l|c|c|}
\hline \multicolumn{1}{|c|}{ Types of Idioms } & Number of Items & \% \\
\hline Pure-idioms & 14 & $23 \%$ \\
\hline Semi-idioms & 31 & $52 \%$ \\
\hline Literal idioms & 15 & $25 \%$ \\
\hline Total & $\mathbf{6 0}$ & $\mathbf{1 0 0 \%}$ \\
\hline
\end{tabular}

There are three types of idioms used in the novel. Semi-idioms is the type which are frequently found in the novel. Then, it is followed by literal idioms. Pure idioms are on the lowest rank.

From 60 idioms found in the novel, 31 idioms are semi-idioms (52\%). Their meanings are considered semi-transparent because they can be seen from one or more constituent parts of the idioms. It means the meaning can be guessed by seeing one or more literal meaning of the constituent parts such as in the idiom 'clapped eyes on'. The meaning of 'clapped eyes on' which is to see someone or something, perhaps for the first time (McGraw-Hill Dictionary of American Idioms and Phrasal Verbs) can be guessed by seeing the words 'eyes on'. People can relate the meaning of this idiom with the 'eyes' which are the part of the body used for seeing things. In addition, there are 15 literal idioms (25\%). This class of idioms allow little variation, and the meaning are transparent as they can be comprehended by looking at the words which formed them. The example of this class is 'don't lose your time'. People can get the meaning of those idioms by seeing at the meaning of the constituent part of the idioms. 'Don't lose your time' means do not let time to be wasted. Besides, 14 idioms are pure idioms (23\%). They are not transparent and non-literal, but they may have little variation. For example, the meaning of the idiom 'on your head be it' cannot be understood just by looking at the part of the idioms. They need to be understood and take as a whole unit. 'On your head be it' is the expression 
used to warn someone that he/she is responsible for something (Collin Cobuild Dictionary of Idioms).

\section{Translation Strategies}

There are three translation strategies used by the translator of the Indonesian version of $A$ Study in Scarlet in translating the idioms found in the English version of the novel.

Table 4 Translation Strategies Used for Translating the Idioms

\begin{tabular}{|l|c|c|}
\hline \multicolumn{1}{|c|}{ Translation Strategies } & Number & $\%$ \\
\hline $\begin{array}{l}\text { Translating an idiom by using an idiom of similar meaning and } \\
\text { form }\end{array}$ & 13 & $22 \%$ \\
\hline $\begin{array}{l}\text { Translating an idiom by using an idiom of similar meaning but } \\
\text { dissimilar form }\end{array}$ & 4 & $7 \%$ \\
\hline Translating an idiom by paraphrasing & 38 & $63 \%$ \\
\hline Translating an idiom by omission & 5 & $8 \%$ \\
\hline \multicolumn{1}{c|}{ Total } & $\mathbf{6 0}$ & $\mathbf{1 0 0 \%}$ \\
\hline
\end{tabular}

The table above shows that translating the idioms by paraphrasing is the strategy which mostly used by the translator. On the second rank there is translating idioms by using idiom of similar meaning and form. Then, it is followed by translating by omission, and on the lowest rank there is translating by using idiom of similar meaning but dissimilar form.

There are 38 idioms translated by paraphrasing (63\%). The translator translates the idioms on the source language by giving their meaning in the target language. The translator uses a single word and a group of words. It is presumably that the translator chooses the meaning which is appropriate to be used in such context. Here is the example of translating idiom by paraphrasing:

\begin{tabular}{|c|c|}
\hline $\begin{array}{l}\text { Source Idiom } \\
\text { (English) }\end{array}$ & $\begin{array}{l}\text { Possible Translation } \\
\text { (Indonesian) }\end{array}$ \\
\hline $\begin{array}{l}\text { I shall work it out on my own hook. } \\
\text { (p.23) }\end{array}$ & $\begin{array}{l}\text { Aku akan menyelidikinya dengan } \\
\text { caraku sendiri. (p.40) }\end{array}$ \\
\hline
\end{tabular}

'On my own hook' belongs to the type of pure idioms. It means someone does something without the help from others. The meaning has nothingto dowith 'hook'. The idiom is translated into 'dengan caraku sendiri' whichcan represent the meaning of the idiom.

Moreover, there are 13 idioms translated by using the idioms of similar meaning and form $(22 \%)$. Here is the example of translating idiom by using idiom of similar meaning and form which means that there is idiom in the target language which is equivalent to the source language both in terms of meaning as well as the form: 


\begin{tabular}{|c|c|}
\hline $\begin{array}{l}\text { Source Idiom } \\
\text { (English) }\end{array}$ & $\begin{array}{c}\text { Possible Translation } \\
\text { (Indonesian) }\end{array}$ \\
\hline $\begin{array}{l}\text { I should have fallen into the hands of } \\
\text { the murderous Ghazis had it not been for } \\
\text { the devotion and courage shown by } \\
\text { Murray, my orderly, who threw me } \\
\text { across a pack-horse, and succeeded in } \\
\text { bringing me safely to the British lines. } \\
\text { (p.5) }\end{array}$ & $\begin{array}{l}\text { Hampir saja aku jatuh ke tangan para Ghazi } \\
\text { yang gemar membunuh, kalau bukan karena } \\
\text { jasa mantriku, Murray. Pemuda itulah yang } \\
\text { dengan berani membawaku di atas punggung } \\
\text { kuda hingga tiba dengan selamat di wilayah } \\
\text { Inggris. (p.8) }\end{array}$ \\
\hline
\end{tabular}

'fallen into the hands of' belongs to the type of semi-idioms. Collin Cobuild Dictionnary of Idioms gave the meaning that if someone or something falls into the hands of an opponent or enemy, they are taken or caught by that person. The idiom is translated into 'jatuh ke tangan' whichis the idiom which has similarity in meaning and form.

In addition, there are 5 idioms translated by omission (8\%). The translator does not translate the source idiom. Actually, omitting the idiom is not wise to be done since the impact of the idiom will be lost. The translator probably choose this strategy because he fails to understand the idiom or because he thinks that without translating the idiom, the message can still be delivered. Here is the example of translating idiom by omission:

\begin{tabular}{|l|l|}
\hline \multicolumn{1}{|c|}{$\begin{array}{c}\text { Source Idiom } \\
\text { (English) }\end{array}$} & \multicolumn{1}{|c|}{$\begin{array}{c}\text { Possible Translation } \\
\text { (Indonesian) }\end{array}$} \\
\hline $\begin{array}{l}\text { "It seems to me, Stamford," I added, } \\
\text { looking hard at my companion, "that you } \\
\text { have some reason for washing your } \\
\text { hands of the matter. Is this fellow's } \\
\text { temper so formidable, or what is it? Don't } \\
\text { be mealy-mouthed about it."(p.7) }\end{array}$ & $\begin{array}{l}\text { "Tempenarnya ada apa sih, Stamford?" } \\
\text { ada masalah lain? Ceritakan terus terang, } \\
\text { jangan berbelit-belit!"(p.12) }\end{array}$ \\
\hline
\end{tabular}

'Washing your hands of the matter' is semi-idioms. The meaning is to end one's association with someone or something (McGraw-Hill Dictionary of American Idioms and Phrasal Verbs). The idiom is not translated into the target text.

Besides, there are 4 idioms translated by using the idioms of similar meaning but dissimilar form (7\%). Here is the example of translating idiom by using idiom of similar meaning but dissimilar form which means that there is idiom in the target language which is equivalent to the source language in terms of meaning but not in the form.

\begin{tabular}{|c|c|}
\hline \multicolumn{1}{|c|}{$\begin{array}{c}\text { Source Idiom } \\
\text { (English) }\end{array}$} & \multicolumn{1}{|c|}{$\begin{array}{c}\text { Possible Translation } \\
\text { (Indonesian) }\end{array}$} \\
\hline $\begin{array}{l}\text { Choosing the latter alternative, I began by } \\
\text { making up my mind to leave the hotel, and } \\
\text { to take up my quarters in some less } \\
\text { pretentious and less expensive domicile. (p.6) }\end{array}$ & $\begin{array}{l}\text { Memilih yang terakhir, aku membulatkan } \\
\text { tekad untuk meninggalkan hotel dan mencari } \\
\text { tempat lain yang tidak semewah dan semahal } \\
\text { hotel tersebut. (p.9) }\end{array}$ \\
\hline
\end{tabular}


'Making up my mind' belongs to the type of semi-idioms. It means to decide about someone or something (McGraw-Hill Dictionary of American Idioms and Phrasal Verbs). The idiom is translated into 'membulatkan tekad' whichhas similar meaning, but the form is different. 'Mind' has nothing to do with the word 'tekad'.

\section{Accuracy, Acceptability, and Readability of Idioms Translation}

Based on the raters'questionnaires, below is the accuracy, acceptability and readability of the translation of idioms in the novel:

Table 5 Accuracy, Acceptability, and Readability of Idioms Translation

\begin{tabular}{|l|l|c|c|c|}
\hline No & \multicolumn{1}{|c|}{ Aspects } & Score & Value & Total \\
\hline 1 & Accuracy & $\mathbf{2 . 6 9}$ & $3 \mathrm{x}$ & 8.07 \\
\hline 2 & Acceptability & $\mathbf{2 . 6 7}$ & $2 \mathrm{x}$ & 5.28 \\
\hline 3 & Readability & $\mathbf{2 . 3 1}$ & $1 \mathrm{x}$ & 2.31 \\
\hline \multicolumn{4}{|c|}{ Score of the quality of translation } & $15.66: 6=\mathbf{2 . 6 1}$ \\
\hline
\end{tabular}

After the questionnaire results were calculated and analysed, it is revealed that the average score for the accuracy of the translation of idiom is 2.69 . The score is more than 2.50 so it belongs to the highest category in accuracy parameter which indicates that the translation is accurate. Eventhough there are still some meaning distortions and omission meanings which can interfere the whole message, most of the meanings of the ST have been transferred accurately into the TT. Besides, it is revealed that the average score for the acceptability of the translation of idiom is 2.67. The score is also more than 2.50 which makes it included into the highest category in acceptability parameter. It indicates that the translation is acceptable. In general the translated text seemed natural although there is still a problem in the use of the idioms or the phrases, and there are some mistakes in the use of Indonesian Language. In addition, it is revealed that the average score for the readability of the translation of idioms is 2.31. The score is less than 2.50 , so it belongs to the second category in readability parameter. It indicates that the translation is less readable. Overall, the translated text is easy to be understood by the readers; however, there is still a part which needs to be read several times before it can be understood. Overall after the calculation, the score for the quality of translation of idioms in the novel is 2.61. It implies that the idiom translation in the novel is good although actually it still can be improved.

\section{Conclusion and Recommendation}

Translating idioms is often problematic for translators because idioms are hard to be understood and specific to a single language. The equivalent of an idiom in another language is hard to find. Therefore, the original and the translation of the novel entitled A Study in Scarlet was analysed. The objectives of the study are to find out the types of idioms found in the English version of A Study in Scarlet, to find out the strategies used by the translator of 
the Indonesian version of A Study in Scarlet in translating the idioms, and to find out the accuracy, acceptability and readability of the translation of idioms in A Study in Scarlet.

The finding of the analysis shows that semi-idiom is the type of idiom which is frequently found in A Study in Scarlet with 31 idioms (52\%). The second position is literal idioms with 15 idioms (25\%), and on the third position there are pure idioms with 14 idioms (23\%). In addition, translating idioms by paraphrasing is mostly used by the translator to translate the idioms found in the novel with 38 idioms (63\%). Then, it is followed by translating an idiom by using the idioms of similar meaning and form with 13 idioms (22\%). After that, translating by omission are 5 idioms $(8 \%)$. In the last place, translating by using the idioms of similar meaning but dissimilar form are 4 idioms (7\%). In addition, it is revealed that the average score for the accuracy of the translation of idiom is 2.69. It indicates that the translation is accurate. The average score for the acceptability of the translation of idiom is 2.67 . It indicates that the translation is acceptable. Moreover, the average score for the readability of the translation of idiom is 2.31 . It indicates that the translation is less readable. Overall, the translation of idiom in the novel is good although it can still be improved.

There are some recommendations for some parties. Especially for translators, it will be useful for them if they are familiar with the idioms of both source language and target language to be able to translate them easier. Knowing the strategies for translating the idioms will also help. Thus, they can produce the accurate, acceptable, and readable translation of idioms. For the next researcher, they can try to analyse the idiom more deeply based on the origin of the idiom or based on the history of the idioms. They can also have more than three competent raters for scoring the accuracy, acceptability, and readability of translation so that the result will be more reliable and accurate.

\section{References}

- Adelnia, A., \& Dastjerdi, H.V. (2011). Translation of idioms: A hard task for the traslator. Theory and Practice in Language Studies, I(7), 879-883. doi:10.4304/tpls.1.7.879-883

- Akbari, Monireh. 2013. Strategies for Translating Idiom. www.academians.org/Media/Default/Articles/August2013/August2013-2.pdf

- Ammer, C. (1997). The American heritage dictionary of idioms. Houghton Mifflin Harcourt Publishing Company.

- Baker, M. (2011). In other words: A course book on translation. Oxon: Routledge.

- Catford, J. C. (1965). A linguistic theory of translation . Great Britain: Oxford University Press.

- Cawthon, D. (2013). Compare and contrast the difference between qualitative and quantitative research. Retrieved December 14, 2014, from http://portal.ngs.edu/ICS/icsfs/Week_4_Discussion_Topic__Qualitative_and_Quantita.doc?target=128099cf-12ed-43af-8ed3-d6656e9366d4.

- Collin Cobuild dictionnary of idiom. (1997). Great Britain: Harper Collins Publishers.

- Doyle, C. (2013). A study in scarlet. USA: Merchant Books .

- Doyle, C. (2014). Sherlock holmes: A study in scarlet. Yogyakarta: Shira Media. 
- Dubay, W. H. (2004). The principles of readability. California: Impact Information.

- Farahani, K. (2005). A framework for translation evaluation. Translation Studies, 3(9).

- Fernando, C. (1996). Idioms and idiomaticity . Oxford: Oxford University Press.

- Hornby, A. (2010). Oxford advanced learner's dictionary. United Kingdom: Oxford University Press.

- Idioms and Phrases. (n.d.). Retrieved from The Free Dictionary by Farlex: http://idioms.thefreedictionary.com

- Judickaite, Ligita \& Pasvenskiene (2009). The translation of idioms in children's cartoons: A comparative analysis of English dialogues and Lithuanian subtitles. Retrieved from vddb.library.lt/fedora/get/LT-eLABa-0001:E.02 2009 D.../DS.005.1.02.ETD (pdf)

- Larson, M. (1984). Meaning based-translation. London: University Press of America.

- Leah, C. (2012). Idioms - gramatically and figurativeness. Retrieved September 1, 2014, from http://www.theroundtable.ro

- Makkai, A. (1972). Idiom structure in English. The Hague: Mouton.

- Makkai, A. (2011). On redefining the idiom. Mechanisms of Linguistic Behavior, XXXVI. Retrieved from http://www.lacus.org/volumes/36

- Mc Carthy, M. \& O’Dell, F. (2006). English idioms in use. Cambridge: Cambridge University Press.

- McLaughlin, G. H. (1969). SMOG grading - a new readability formula. Journal of Reading(22), 640.

- Nababan, M., Nuraeni, A., \& Sumardiono. (2012). Pengembangan model penilaian kualitas terjemahan. Kajian Linguistik dan Sastra, XXIV(1), 39-57. Retrieved from http://www.publikasiilmiah.ums.ac.id

- Neill, J. (2007). Qualitative versus quantitative research: Key points in a classic debate. Retrieved December 14, 2014, from http://wilderdom.com/research/QualitativeVersusQuantitativeResearch.html

- Newmark, P. (1988). A textbook of translation. New York: Prentice Hall.

- Nida, E.A., \& Taber, C.R. (1982). The theory and practice of translation. Leiden: E.J. Brill.

- Oxford advanced learner's dictionnary 8th edition CD-ROM. (n.d.). Oxford, UK: Oxford University Press.

- Richard, J. C., \& Schmidt, R. (2010). Dictionary of teaching and applied linguistics. London: Longman.

- Schoenbeck, R. (2013). Retrieved from Center for Excellence in Writing and Communication: http://www.writingcenter.uci.edu/what-is-analysis-and-why-does-mywriting-instructor-keep-asking-for-it-part-i/

- Shojaei, Amir. 2012. Translation of idioms and fixed expressions: Strategies and difficulties.www.academia.edu/.../Translation_of_Idioms_and_Fixed_Expressions_..

- Shuttleworth, M. \& Cowie, M. (1997). Dictionary of translation studies. Manchester: STJEROME.

- Siefring, J. (2004). Oxford dictionnary of idiom. New York: Oxford University Press.

- Spears, R. (2005). McGraw-hill dictionary of American idioms and phrasal verbs. McGraw-Hills. 
- Staksiene. Margarita. (2010) . Analysis of idiom translation strategies from English into Rusian.Retrieved Dec. 02, 2016 from www.kalbos.It/zurnalai/17_numeris/04.pdf

- Toury, G. (1995). The nature and role of norms in translation. Amsterdam and Philadelphia: John Benjamins.

- Walter, E. (Ed.). (2008). Cambridge advanced learner's dictionnary 3rd edition CD-ROM. Cambridge, UK: Cambridge Uiversity Press.

- Wang, L., \& Wang, S. (2013). A study of idiom translation strategies between english and chinese. Theory and Practice in Language Studies, III (9), 1691-1697. doi:10.4304/tpls.3.9.1691-1697 